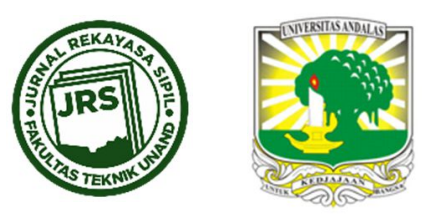

\title{
IMPLEMENTASI LAST PLANNER SYSTEM PADA PROYEK DI PALEMBANG (STUDI KASUS: PROYEK RUSUNAMI JAKABARING)
}

\author{
EVRIZA KHOIRUNNISA ${ }^{1}$, MONA FORALISA TOYFUR ${ }^{2}$, BETTY SUSANTI ${ }^{3}$ \\ ${ }^{1}$ Jurusan Teknik Sipil, Fakultas Teknik, Universitas Sriwijaya (evrizza.khoirunnisa@gmail.com) \\ ${ }^{2}$ Jurusan Teknik Sipil, Fakultas Teknik, Universitas Sriwijaya (Corresponding author $ه$ : mforalisa@yahoo.com) \\ ${ }^{3}$ Jurusan Teknik Sipil, Fakultas Teknik, Universitas Sriwijaya (bettysusantio4o1@gmail.com)
}

Naskah diterima : 14 November 2018. Disetujui: 20 April 2019. Diterbitkan : 24 Mei 2019

\section{ABSTRAK}

Saat ini sektor konstruksi mulai melakukan upaya untuk mengurangi waste sekaligus meningkatkan value dengan mengadopsi teori produksi pada industri manufaktur kepada industri konstruksi yang disebut lean construction (konstruksi ramping). Sistem pengendalian produksi (production control) dengan konsep konstruksi ramping merupakan salah satu sistem dalam perencanaan dan pengendalian jadwal pekerjaan. Komponen yang terdapat konsep konstruksi ramping tersebut adalah sistem the Last Planner (LPS). Last Planner System belum banyak digunakan dan mempunyai potensi yang baik karena merupakan bagian dari komponen lean construction dimana dalam perencanaannya semua pihak dapat terlibat secara langsung dan terkoordinasi sehingga pekerjaan yang direncanakan dapat terkontrol dengan baik dalam pelaksanaannya. Setelah melakukan analisis progress kerja harian, LPS mempunyai indikator kinerja yang digunakan untuk mengukur sejauh mana aliran pekerjaan dapat tercapai dengan baik, adapun kontrol aliran kerja Last Planner System yaitu Master Plan, Phase Planning dan Pull Planning, Lookahead Planning, Constraints Analysis, Shielding Production, Weekly Work Plan dan Percent Plan Complete (PPC) sebagai standar untuk mengontrol unit-unit produksi, menentukan jadwal proyek, strategi pelaksanaan, dan lain-lain. Pada penelitian ini, hasil rata-rata PPC adalah $73 \%$. Tujuan dilakukannya penelitian dengan metode LPS ini yaitu untuk menganalisis implementasi konsep Last Planner System yang dibandingkan dengan progress aktual dalam meningkatkan reliabilitas pekerjaan harian dan Melakukan evaluasi kinerja pekerjaan kontraktor menggunakan LPS. Metodologi yang digunakan pada penelitian ini menggunakan kurva $\mathrm{S}$, data progress rencana dan aktual mingguan proyek juga dilakukan pengolahan data dengan konsep aliran kerja LPS. Untuk membuktikan bahwa perhitungan PPC yang dilakukan sesuai dengan kondisi di lokasi proyek, maka dilakukan perbandingan data dari hasil perhitungan PPC menggunakan LPS dengan progress data mingguan di lokasi proyek yang didapat dari pihak kontraktor. Dari hasil perbandingan data tersebut dapat dilihat bahwa hasil PPC mingguan tidak jauh berbeda dengan hasil data progress mingguan yang didapat dari pihak kontraktor. Hal ini membuktikan bahwa LPS dapat meningkatkan reabilitas perencanaan di atas 70\% sehingga tingkat resiko terjadinya keterlambatan proyek akan semakin kecil.

Kata kunci : Lean construction, Last planner system 


\section{PENDAHULUAN}

Metode pelaksanaan yang digunakan dalam dunia konstruksi selalu berkembang. Namun, dunia konstruksi masih berusaha untuk menghadapi masalah-masalah yang diakibatkan oleh waste dengan jumlah yang sangat besar.

Waste dapat berupa segala bentuk kegiatan yang menggunakan sumber daya namun tidak menambah nilai (value), (Mudzakir, 2017). Bentuk permasalahan waste seperti keterlambatan waktu pelaksanaan proyek konstruksi ini masih menjadi masalah utama yang dihadapi dunia konstruksi Indonesia.

Saat ini sektor konstruksi mulai melakukan upaya untuk mengurangi waste sekaligus meningkatkan value dengan mengadopsi teori produksi pada industri manufaktur kepada industri konstruksi yang disebut lean construction (konstruksi ramping). Sistem pengendalian produksi (production control) dengan konsep konstruksi ramping merupakan salah satu sistem dalam perencanaan dan pengendalian jadwal pekerjaan. Komponen yang terdapat konsep konstruksi ramping tersebut adalah sistem the Last Planner(LPS).

LPS belum banyak digunakan dan mempunyai potensi yang baik karena merupakan bagian dari komponen lean construction dimana dalam perencanaannya semua pihak dapat terlibat secara langsung dan terkoordinasi sehingga pekerjaan yang direncanakan dapat terkontrol dengan baik dalam pelaksanaannya. LPS telah terbukti efektif dalam mencapai dan mempertahankan rencana kerja di atas 70\%, (Ballard, 2000). Penelitian menggunakan konsep LPS ini biasanya digunakan pada proyek pembangunan gedung. Sehingga dalam hal ini, penelitian ini akan mengimplementasikan konsep Last Planner System (LPS) pada proyek konstruksi dan evaluasi progress pekerjaan pada proyek pembangunan dengan studi kasus proyek pembangunan Rusunami Jakabaring, Palembang.

Adapun tujuan penelitian yaitu :

1. Menganalisis implementasi konsep Last Planner System yang dibandingkan dengan progress aktual dalam meningkatkan reliabilitas pekerjaan harian pada proyek pembangunan Rusunami Jakabaring.

2. Melakukan evaluasi kinerja pekerjaan kontraktor menggunakan LPS pada proyek pembangunan Rusunami Jakabaring.

Ruang lingkup pada penelitian ini dilakukan di proyek pembangunan Rusunami Jakabaring, Palembang dengan pengamatan yang difokuskan pada pekerjaan finishing/arsitektur di lokasi proyek..

\section{LAST PLANNER SYSTEM}

\subsection{Konstruksi ramping (lean contruction)}

Lean Construction adalah membangun proyek sekaligus memberi nilai, meminimasi limbah, dan mencapai kesempurnaan untuk keuntungan semua stakeholder. (Pinch, 2005). Manfaat dari teknik Lean Construction telah ditunjukkan dengan pencapaian peningkatan dari banyak proyek dan setiap tahapan proyek. Lean Construction memerlukan lebih banyak waktu dalam tahap desain dan perencanaan, tetapi perhatian ini menghilangkan atau memperkecil konflik yang dapat secara dramatis mengubah biaya dan jadwal. (Forbes, dkk, 2005). 
Hasil penelitian yang diperoleh oleh Munje dan Patil (2014), adalah perbandingan antara konstruksi tradisional dengan lean construction. Pada penelitian dijelaskan bahwa ada banyak kesempatan untuk menghilangkan kelemahan dalam konstruksi tradisional menggunakan proses proyek. Last Planner System, diterapkan dapat meningkatkan metode tradisional dan menyiratkan budaya perbaikan terus-menerus dan mengurangi waktu dan biaya secara bersamaan.

\subsection{Last planner system (LPS)}

Ballard, (2000) melakukan penelitian untuk mengetahui apakah LPS dapat meningkatkan reabilitas rencana pekerjaan dengan PPC di atas $70 \%$. Penelitian dilakukan dibeberapa proyek konstruksi, yaitu:

1. CCSR Project dengan weekly PPC rata-rata adalah $71 \%$ dan reason not completion terbanyak adalah pre-requisite work.

2. Next Stage Project dengan weekly PPC rata-rata adalah $57 \%$ dan reason not completion terbanyak adalah pre-requisite work.

3. Pacific Contracting dengan weekly PPC rata-rata adalah $67 \%$ dan reason not completion terbanyak adalah plan.

4. Old Chemistry Building Renovation Project dengan weekly PPC rata-rata adalah $84 \%$ dan reason not completion terbanyak adalah pre-requisite work.

5. Zeneca Project dengan weekly PPC rata-rata adalah $89 \%$ dan reason not completion terbanyak adalah faktor tenaga kerja.

Penelitian tersebut menyimpulkan bahwa LPS dapat meningkatkan reabilitas perencanaan di atas $70 \%$. Hasil penelitian tersebut menggunakan PPC mingguan dengan melakukan penelitian dari awal proyek hingga akhir proyek, berbeda dengan penelitian ini yang dilakukan mendekati akhir proyek sehingga digunakan PPC harian.

\subsection{Kontrol Aliran Kerja LPS}

Dalam sistem ini, terdapat indikator kinerja yang digunakan untuk mengukur sejauh mana aliran pekerjaan dapat tercapai dengan baik, adapun kontrol aliran kerja Last Planner System yaitu:

\subsubsection{Master plan}

Untuk mendapatkan rencana umum dan mengidentifikasi semua pekerjaan untuk keseluruhan proyek menunjukkan kegiatan utama, durasi, dan urutan.

\subsubsection{Phase planning dan pull planning}

Fungsi dari phase planning adalah menghasilkan jadwal rinci yang mencakup setiap fase proyek sebagai fondasi dalam menentukan perencanaan lebih lanjut, kerangka struktural, dan finishing. Dalam membuat phase planning ini, lebih menguntungkan jika dikerjakan bersama tim. (Ballard dan Howell, 2004).

Pekerjaan-pekerjaan pada phase planning akan dikembangkan terlebih dahulu menjadi assignments (tugas-tugas) sesuai dengan tingkat detail yang diinginkan. Dalam proses ini secara bersamaan akan dibuat pull planning dimana anggota tim proyek menentukan bagaimana pekerjaan proyek tersebut dikerjakan untuk mencapai hasil pada jadwal yang telah ditetapkan/milestone. (Lean Construction Institute, 2015). Proses pull planning dijabarkan sebagai berikut: 
1. Semua anggota tim yang bertanggung jawab untuk melakukan assignment (tugas) akan berpartisipasi dalam membuat Phase Pull Schedule(PPS).

2. PPS dibuat bersama-sama dengan pihak yang terkait (tim) untuk menetapkan konteks, menentukan jadwal, mencari strategi eksekusi, mengidentifikasi assignments dan mengatur tim dalam bekerja. Semua assignments di PPS harus dapat didefinisikan dan diterima oleh owner.

3. PPS selesai ketika anggota tim menyepakati kriteria assignments yang diberikan antara kegiatan, urutan, dan prakiraan waktu pekerjaan, serta sumber daya (material, labour, and cost) untuk menyelesaikan assignment tersebut. (Patel, 2011).

Adapun contoh proses pembuatan PPS yang dilaksanakan secara bersama-sama dengan tim yang terlibat dalam kegiatan sebuah proyek dapat dilihat pada Gambar 1.

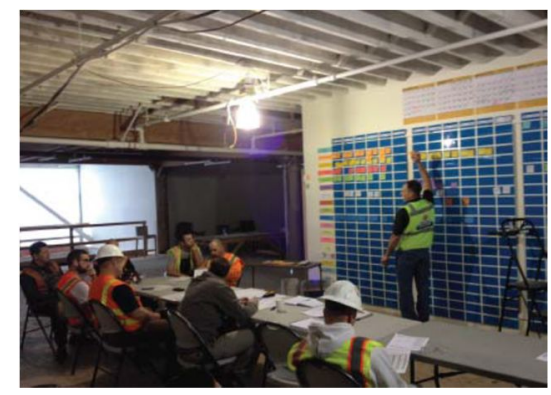

Gambar 1. Proses Pull Planning (Herry, 2015)

\subsubsection{Lookahead planning}

Lookahead planning menggambarkan langkah pertama dari perencanaan LPS dengan jangka waktu biasanya antara dua sampai enam minggu, lalu mengambil tindakan di masa sekarang sehingga tidak menyebabkan pekerjaan tambahan di masa depan. Inti dari proses lookahead ini adalah sebuah schedule yang berisi pekerjaan-pekerjaan yang berpotensi untuk dikerjakan. Beberapa assignments yang masuk dalam lookahead planning dilakukan constraints analysis untuk dapat benar-benar dilaksanakan. (Ballard, 2000).

\subsubsection{Constraints analysis}

Constraints analysis adalah hambatan yang dapat berupa kontrak, desain, submittals, material, pekerjaan prasyarat, ruang/area kerja, peralatan, pekerja dan lain-lain. Hambatanhambatan lain mungkin dapat berupa perizinan, pengawasan, persetujuan, dan sebagainya tergantung dari karakteristik proyek yang bersangkutan (Ballard, 2000). Untuk dapat melakukan constraints analysis, memerlukan kerjasama dengan seluruh pihak yang terlibat. Bila constraints analysis ini tidak dilakukan maka akan cenderung terlalu reaktif bila sesuatu tiba-tiba terjadi dalam pelaksanaan proyek (Steven, dkk, 2013).

\subsubsection{Shielding production}

Dengan membuat assignments yang berkualitas atau melakukan shielding production maka akan dapat melindungi unit-unit produksi dari aliran kerja yang tidak pasti (uncertainty work flow), membuat unit-unit tersebut untuk meningkatkan produktifitas, dan juga untuk meningkatkan produktifitas dari unit-unit produksi selanjutnya sehingga dapat membantu untuk mengurangi durasi proyek (Steven, dkk, 2013). 


\subsubsection{Weekly work plan (WWP)}

WWP merupakan rencana paling rinci dalam LPS. WWP diambil dari tugas kontraktor untuk hari atau minggu berikutnya melalui pertemuan mingguan. bantuan pertemuan mingguan untuk merencanakan pekerjaan yang akan dilakukan pada minggu depan. Pertemuan rencana kerja mingguan meliputi rencana mingguan, masalah keamanan, masalah kualitas, sumber daya, metode konstruksi, dan masalah yang terjadi di lapangan.

WWP menggambarkan secara langsung keterkaitan tugas-tugas pekerjaan untuk mendorong proses produksi. Pada akhir setiap periode dilakukan monitoring dan evaluasi untuk menganalisa apakah rencana yang dibuat efektif, dan kendala apa yang dihadapi. (Ballard, 2000).

\subsection{Percent Plan Complete (PPC)}

PPC adalah jumlah assignments yang telah diselesaikan dibagi dengan jumlah semua assignment rencana, dan ditulis dalam bentuk persentase. (Ballard, 2000). Adapun persamaannya adalah sebagai berikut:

$$
\mathrm{PPC}=\frac{\text { Jumlah rencana pekerjaan yang berhasil dilakukan }}{\text { total rencana peker jaan }} \times 100 \%
$$

PPC merupakan ukuran sejauh mana komitmen dalam melaksanakan pekerjaan yang telah direncanakan telah diwujudkan. PPC dapat dijadikan sebagai standar untuk mengontrol unit-unit produksi, menentukan jadwal proyek, strategi pelaksanaan, dan lain-lain. PPC yang tinggi menunjukkan pekerjaan yang selesai dilakukan dengan sumber daya yang tersedia semakin banyak, produktivitas tinggi dan progres semakin cepat. (Ballard, 2000).

\section{HASIL DAN PEMBAHASAN}

Penelitian ini dilakukan dengan studi kasus pada proyek pembangunan tower 2 Rusunami Jakabaring yang berlokasi di Jalan Silaberanti, Seberang Ulu I, Palembang. Pembangunan tower 2 dilaksanakan pada tahun 2017 dengan komponen pekerjaan secara umum meliputi pekerjaan struktur hingga arsitektur (finishing). Proyek ini dikerjakan oleh PT. PP (Persero) sebagai Kontraktor dan PT. Deta Decon sebagai Konsultan Manajemen Konstruksi.

Proyek pembangunan tower 2 Rusunami Jakabaring ini dikerjakan dari tanggal 11 September 2017 sampai dengan batas kontrak yaitu pada tanggal 30 April 2018 atau pada minggu ke 33. Sedangkan Penelitian dilakukan selama tujuh minggu yaitu dari minggu ke 27 sampai minggu ke 33 (akhir kontrak). Pada minggu awal pengamatan, progress pekerjaan yang telah dicapai adalah $69,62 \%$ dengan deviasi $-13,12 \%$ dari progress rencana. Oleh karena itu, pengamatan pada penelitian ini terbatas pada sisa pekerjaan, yaitu pekerjaan finishing/arsitektur dikarenakan proyek hampir memasuki periode akhir pelaksanaan.

\subsection{Implementasi dengan Menggunakan LPS}

Setelah identifikasi pekerjaan yang diamati sebagaimana telah dijelaskan sebelumnya, dilakukan langkah-langkah perencanaan kerja menggunakan konsep LPS sebagai berikut: 


\subsubsection{Analisis kinerja}

Langkah awal adalah dilakukan analisis kinerja pekerjaan pada minggu ke-27 yaitu tanggal 12 Maret sampai 18 Maret 2018. Tujuan analisis kinerja ini untuk mengukur progress kerja harian pada pekerjaan-pekerjaan yang diamati.

Analisis kinerja dilakukan dengan menganalisis progress kerja harian, dimana langkahlangkah analisis progress kerja harian adalah sebagai berikut:

1. Pengamatan dilakukan pada volume pekerjaan secara langsung di lokasi proyek setiap hari selama satu minggu kerja dan ditinjau per satuan volume pekerjaan $\left(\right.$ dalam $\left.\mathrm{m}^{2}\right)$.

2. Pengukuran volume pekerjaan dilakukan pada bagian pekerjaan yang belum dikerjakan pada setiap tanggal dari tanggal 5 Maret sampai 11 Maret 2018.

3. Selanjutnya, volume total assignment pada masing-masing assignment dikurangi dengan volume pekerjaan yang belum dikerjakan pada setiap tanggal di masing-masing assignment. Didapatkan volume pekerjaan yang telah selesai sampai tanggal yang ditinjau setiap tanggalnya pada masing-masing assignment.

4. Volume pekerjaan yang telah selesai dikerjakan sampai tanggal yang ditinjau pada masing-masing assignment dikurangi dengan volume pekerjaan yang telah selesai sampai tanggal sebelumnya pada masing-masing assignment, maka didapatkan volume pekerjaan harian pada tanggal yang ditinjau.

5. Kemudian volume pekerjaan harian dengan satuan meter persegi dikonversi menjadi progress pekerjaan harian ( $\mathrm{PPH}$ ) dalam bentuk persentase dengan rumus di bawah ini:

$$
\text { PPH }(\%)=\frac{\text { vol.pekerjaan harian tanggal ditinjau }}{\text { vol pekerjaan total }} \times 100 \%
$$

6. Selanjutnya dihitung progress kerja rata-rata harian $(\mathrm{PKRH})$ dengan rumus berikut:

$$
\text { PKRH }(\%)=\frac{\sum \text { Progress kerja harian (\%) }}{\text { jumlah progress kerja harian }}
$$

Hasil perhitungan progress pekerjaan masing-masing assignment sampai minggu 27 dapat dilihat pada Tabel 1 berikut.

Tabel 1. Pengamatan Progress Sampai Minggu 27 Assignments Selama Penelitian

\begin{tabular}{lll}
\hline Area & Assignment & Progress Sampai 18 Maret (\%) \\
\hline Lantai 5 & Pekerjaan dinding & $78,72 \%$ \\
\cline { 2 - 3 } & Pekerjaan Plafon & $23,07 \%$ \\
\cline { 2 - 3 } & Pekerjaan Keramik & $56,28 \%$ \\
\cline { 2 - 3 } & Pekerjaan Pengecatan & $0,00 \%$ \\
\hline Lantai 6 & Pekerjaan dinding & $78,67 \%$ \\
\cline { 2 - 3 } & Pekerjaan Plafon & $21,00 \%$ \\
\cline { 2 - 3 } & Pekerjaan Keramik & $22,45 \%$ \\
\cline { 2 - 3 } Lantai 7 & Pekerjaan Pengecatan & $0,00 \%$ \\
\cline { 2 - 3 } & Pekerjaan dinding & $73,54 \%$ \\
\cline { 2 - 3 } & Pekerjaan Plafon Keramik & $20,28 \%$ \\
\cline { 2 - 3 } & Pekerjaan Pengecatan & $0,00 \%$ \\
\cline { 2 - 3 } & Pekerjaan dinding & $68,79 \%$ \\
\hline Lantai 8 & Pekerjaan Plafon & $16,07 \%$ \\
\hline
\end{tabular}




\begin{tabular}{lll}
\hline Area & Assignment & Progress Sampai 18 Maret (\%) \\
\cline { 2 - 3 } & Pekerjaan Keramik & $6,39 \%$ \\
\hline Lantai 9 9 9 Pekerjaan Pengecatan & $0,00 \%$ \\
\cline { 2 - 3 } & Pekerjaan Planding & $39,28 \%$ \\
\cline { 2 - 3 } & Pekerjaan Keramik & $0,00 \%$ \\
\cline { 2 - 3 } & Pekerjaan Pengecatan & $0,00 \%$ \\
\hline Lantai 10 $10 \%$ \\
\cline { 2 - 3 } & Pekerjaan dinding & $52,70 \%$ \\
\cline { 2 - 3 } & Pekerjaan Plafon & $14,53 \%$ \\
\cline { 2 - 3 } & Pekerjaan Keramik & $0,00 \%$ \\
\hline
\end{tabular}

\subsection{Kontrol Aliran LPS}

Hasil dari analisis kinerja digunakan dalam pembuatan kontrol aliran kerja LPS. Langkahlangkah umum kontrol aliran kerja LPS berturut-turut yaitu pembuatan master plan, phase plan dan pull plan, pembuatan lookahead plan, weekly work plan (WWP), constrain analysis, shielding production analysis, dan evaluasi yang berupa perhitungan Percent Plan Completed(PPC).

\subsubsection{Master plan}

Master plan merupakan jadwal yang berisi pekerjaan-pekerjaan utama proyek. Dari master plan ini diperoleh bahwa proyek dimulai pada tanggal 11 September 2017 dan direncanakan selesai pada tanggal 30 April 2018. Penelitian ini dilakukan pada periode tanggal 12 Maret sampai dengan 30 April 2018 (batas akhir kontrak). Secara umum pekerjaan yang diamati adalah sisa pekerjaan finishing pada lantai 5 hingga lantai 10 yang meliputi pekerjaan dinding, pekerjaan plafon, pekerjaan pemasangan keramik, dan pekerjaan pengecatan. Pada Tabel 2 menunjukkan daftar pekerjaan yang diamati dalam penelitian ini.

Tabel 2. Pekerjaan yang Diamati

\begin{tabular}{llll}
\hline \multirow{2}{*}{ Area } & Assignments & $\begin{array}{l}\text { Volume Total } \\
\text { Assignments }\end{array}$ & Units \\
\hline Lantai 5 & Pekerjaan dinding & 1880,28 & $\mathrm{~m}^{2}$ \\
\cline { 2 - 4 } & Pekerjaan Plafon & 1622,24 & $\mathrm{~m}^{2}$ \\
\cline { 2 - 4 } & Pekerjaan Keramik & 1306,15 & $\mathrm{~m}^{2}$ \\
\hline Lantai 5 & Pekerjaan Pengecatan & 2856,09 & $\mathrm{~m}^{2}$ \\
\hline Lantai 6 & Pekerjaan dinding & 1893,91 & $\mathrm{~m}^{2}$ \\
\cline { 2 - 4 } & Pekerjaan Plafon & 1622,82 & $\mathrm{~m}^{2}$ \\
\cline { 2 - 4 } & Pekerjaan Keramik & 1365,22 & $\mathrm{~m}^{2}$ \\
\cline { 2 - 4 } & Pekerjaan Pengecatan & 2869,72 & $\mathrm{~m}^{2}$ \\
\hline Lantai 7 & Pekerjaan dinding & 1893,91 & $\mathrm{~m}^{2}$ \\
\cline { 2 - 4 } & Pekerjaan Plafon & 1622,82 & $\mathrm{~m}^{2}$ \\
\cline { 2 - 4 } & Pekerjaan Keramik & 1365,22 & $\mathrm{~m}^{2}$ \\
\cline { 2 - 4 } & Pekerjaan Pengecatan & 2869,72 & $\mathrm{~m}^{2}$ \\
\hline Lantai 8 & Pekerjaan dinding & 1893,91 & $\mathrm{~m}^{2}$ \\
\cline { 2 - 4 } & Pekerjaan Plafon & 1622,82 & $\mathrm{~m}^{2}$ \\
\cline { 2 - 4 } & Pekerjaan Keramik & 1365,22 & $\mathrm{~m}^{2}$ \\
\cline { 2 - 4 } & Pekerjaan Pengecatan & 2869,72 & $\mathrm{~m}^{2}$ \\
\hline Lantai 9 & Pekerjaan dinding & 1893,91 & $\mathrm{~m}^{2}$ \\
\cline { 2 - 4 } & Pekerjaan Plafon & 1622,82 & $\mathrm{~m}^{2}$ \\
\cline { 2 - 4 } & Pekerjaan Keramik & 1365,22 & $\mathrm{~m}^{2}$ \\
\cline { 2 - 4 } & Pekerjaan Pengecatan & 2869,72 & $\mathrm{~m}^{2}$ \\
\hline Lantai 10 & Pekerjaan dinding & 2182,48 & \\
\hline
\end{tabular}


Implementasi Last Planner System Pada Proyek di Palembang (Studi Kasus : Proyek Rusunami Jakabaring)

\begin{tabular}{|c|c|c|c|}
\hline Area & Assignments & $\begin{array}{l}\text { Volume Total } \\
\text { Assignments }\end{array}$ & Units \\
\hline & Pekerjaan Plafon & 1622,82 & $\mathrm{~m}^{2}$ \\
\hline & Pekerjaan Keramik & 1365,22 & $\mathrm{~m}^{2}$ \\
\hline & Pekerjaan Pengecatan & 3158.29 & $\mathrm{~m}^{2}$ \\
\hline
\end{tabular}

Selanjutnya masing-masing assignments akan didefiniskan menggunakan sticky notes dengan warna yang berbeda-beda. Warna-warna tersebut nantinya berfungsi dalam pembuatan perencanaan menggunakan LPS sebelum dilakukan monitoring dan evaluasi progress pekerjaan.

\subsubsection{Pembuatan phase plan dan pull plan}

Phase plan adalah perencanaan sub-sub pekerjaan dari awal hingga akhir proyek. Pada penelitian ini phase plan tidak dilakukan karena pekerjaan yang diamati hanya pada pekerjaan finishing saja. Karena pembuatan phase pull planning tidak dapat dilakukan sebagai bagian dari analisis kontrol aliran kerja, maka penelitian ini difokuskan pada analisis untuk mengatasi keterlambatan yang dilakukan pada detil pekerjaan.

\subsubsection{Pembuatan lookahead plan}

Lookahead plan adalah rencana kerja dua sampai enam minggu kedepan. Pembuatan lookahead plan dilakukan secara pushing yaitu mendorong jadwal breakdown pekerjaan dari awal periode proyek ke dua sampai enam minggu ke depan. Pembuatan lookahead plan pada penelitian ini diasumsikan tidak terdapat addendum berupa penambahan waktu pekerjaan sehingga akhir pelaksanaan proyek/milestone berakhir pada tanggal 30 April 2018. Periode lookahead plan diambil lima minggu. Langkah-langkah pembuatan lookahead plan sebagai berikut:

1. Lookahead plan dibuat dengan menggunakan lean tools berupa sticky note dan flip papper dari kertas manila yang diberi garis berupa kolom kolom. Format dan contoh pengisian sticky note untuk lookahead plan dapat dilihat pada Gambar 2.

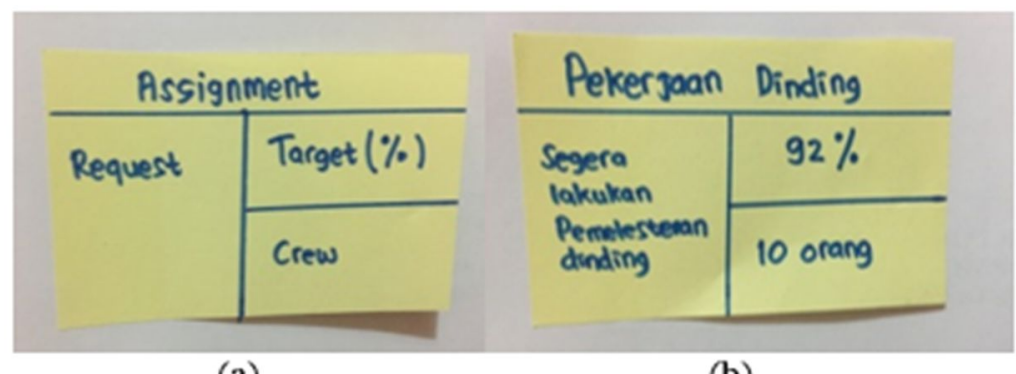

(a)

(b)

Gambar 2. Format (A) dan (B) Contoh Pengisian Sticky Note

2. Dibuat analisis perkiraan keterlambatan pekerjaan. Analisis ini mengacu pada progress kerja harian/orang. Penggunaan data tersebut dikarenakan pengaruh perpindahan pekerja antar lantai pada tanggal tertentu. Kemudian dilakukan perhitungan dengan cara seperti pada Tabel 3. 
Tabel 3. Cara perhitungan progress pekerjaan sampai tanggal tertentu

\begin{tabular}{|c|c|c|c|}
\hline Tanggal n1 & Tanggal n2 & Tanggal n3 & Tanggal ni \\
\hline \multirow{3}{*}{$\begin{array}{l}\text { Progress } \\
\text { Sampai n1 }\end{array}$} & Progress sampai tanggal & \multirow{3}{*}{$\begin{array}{l}\text { Progress sampai tanggal n3 = } \\
\text { progress tanggal n2 + } \\
\text { progress kerja/orang/hari } \mathrm{x} \\
\text { jumlah pekerja }\end{array}$} & \multirow{2}{*}{$\begin{array}{l}\text { Progress sampai tanggal } \\
\text { n } i=\text { progress tanggal n } i+ \\
\text { progress }\end{array}$} \\
\hline & $\begin{array}{lr}\mathrm{n} 2=\text { progress tanggal } \mathrm{n} 1 \\
+\quad \text { progress }\end{array}$ & & \\
\hline & $\begin{array}{ll}\text { kerja/orang/hari } & \mathrm{x} \\
\text { jumlah pekerja } & \end{array}$ & & $\begin{array}{l}\text { kerja/orang/hari } \\
\text { jumlah pekerja }\end{array}$ \\
\hline
\end{tabular}

Dilangkah ini, progress kerja harian setiap pekerjaper hari diasumsikan tidak berubah. Langkah ini selesai jika progress pekerjaan telah mencapai $100 \%$ pada setiap pekerjaan atau jadwal pekerjaan telah mencapai milestone.

\subsubsection{Weekly Work Plan (WWP) dan Daily Work Plan (DWP)}

WWP adalah planning dengan melihat lookahead plan dalam seminggu sehingga rencana pekerjaan lebih focus pada minggu yang ditinjau. Dalam penelitian ini karena pekerjaan yang diamati sedikit dalam waktu yang relatif singkat maka ditambahkan istilah Daily Work Plan (DWP) yaitu melihat pekerjaan pada hari atau tanggal yang ditinjau. DWP kemudian dimasukkan dalam tabel DWP yang dapat dilihat pada Tabel 4 yang diisi di awal hari (pagi hari) pada tanggal yang ditinjau.

Tabel 4. DWP tanggal 19 maret

\begin{tabular}{|c|c|c|c|c|c|}
\hline \multirow[t]{2}{*}{ Area } & \multirow{2}{*}{ Assignment } & \multirow{2}{*}{$\begin{array}{l}\text { Progress kerja harian } \\
\text { rencana tanggal } 19 \text { Maret }\end{array}$} & \multirow{2}{*}{$\begin{array}{l}\text { Progress } \\
\text { sampai } \\
\text { Maret }\end{array}$} & rencana & \multirow{2}{*}{$\begin{array}{l}\text { Pekerja } \\
\text { (orang) }\end{array}$} \\
\hline & & & & tanggal 19 & \\
\hline \multirow[t]{3}{*}{ Lantai 5} & Pekerjaan dinding & $2 \%$ & & $81 \%$ & 5 \\
\hline & Pekerjaan Plafon & $3 \%$ & & $26 \%$ & 6 \\
\hline & $\begin{array}{l}\text { Pekerjaan } \\
\text { Keramik }\end{array}$ & $4 \%$ & & $60 \%$ & 4 \\
\hline \multirow[t]{3}{*}{ Lantai 6} & Pekerjaan dinding & $2 \%$ & & $81 \%$ & 4 \\
\hline & Pekerjaan Plafon & $4 \%$ & & $25 \%$ & 12 \\
\hline & $\begin{array}{l}\text { Pekerjaan } \\
\text { Keramik }\end{array}$ & $3 \%$ & & $26 \%$ & 4 \\
\hline \multirow[t]{4}{*}{ Lantai 7} & Pekerjaan dinding & $2 \%$ & & $76 \%$ & 7 \\
\hline & Pekerjaan Plafon & $2 \%$ & & $22 \%$ & 7 \\
\hline & Pekerjaan & $4 \%$ & & $31 \%$ & 6 \\
\hline & Keramik & & & & \\
\hline \multirow[t]{4}{*}{ Lantai 8} & Pekerjaan dinding & $2 \%$ & & $71 \%$ & 6 \\
\hline & Pekerjaan Plafon & $2 \%$ & & $18 \%$ & 8 \\
\hline & Pekerjaan & $1 \%$ & & $10 \%$ & 5 \\
\hline & Keramik & & & & \\
\hline \multirow[t]{4}{*}{ Lantai 9} & Pekerjaan dinding & $4 \%$ & & $43 \%$ & 7 \\
\hline & Pekerjaan Plafon & $3 \%$ & & $3 \%$ & 7 \\
\hline & Pekerjaan & $3 \%$ & & $3 \%$ & 6 \\
\hline & Keramık & & & & \\
\hline \multirow{4}{*}{$\begin{array}{l}\text { Lantai } \\
10\end{array}$} & Pekerjaan dinding & $2 \%$ & & $55 \%$ & 7 \\
\hline & Pekerjaan Plafon & $3 \%$ & & $18 \%$ & 8 \\
\hline & Pekerjaan & $3 \%$ & & $3 \%$ & 6 \\
\hline & Keramik & & & & \\
\hline
\end{tabular}

\subsubsection{Constrain analysis}

Tujuan dari constrain analysis adalah mengidentifikasi hambatan-hambatan sebelum pelaksanaan assignment. Pada penelitian ini, constrain analysis dilakukan setiap hari di pagi hari. Kriteria constrain dalam penelitian ini sebagai berikut: 
1. Submittals yaitu permohonan atau pengajuan pelaksanaan pekerjaan

2. Material yaitu tersedianya bahan yang digunakan dalam pelaksanaan

3. Space yaitu tersedianya tempat untuk melaksanakan pekerjaan

4. Alat yaitu tersedianya peralatan untuk melaksanakan pekerjaan

5. Pekerja yaitu tersedianya tenaga kerja terutama tukang/pekerja untuk melaksanakan pekerjaan

Tabel 5. Constrain analysis untuk DWP tanggal 19 Maret

\begin{tabular}{|c|c|c|c|c|c|c|}
\hline Area & Assignment & $\begin{array}{l}\text { Submittal } \\
\text { s }\end{array}$ & Material & $\begin{array}{l}\text { Spac } \\
e\end{array}$ & Alat & Pekerja \\
\hline \multirow[t]{3}{*}{ Lantai 5} & Pekerjaan dinding & $\checkmark$ & $\checkmark$ & $\checkmark$ & $\checkmark$ & $\checkmark$ \\
\hline & Pekerjaan Plafon & $\checkmark$ & $\checkmark$ & $\checkmark$ & $\checkmark$ & $\checkmark$ \\
\hline & Pekerjaan Keramik & $\checkmark$ & $\checkmark$ & $\checkmark$ & $\checkmark$ & $\checkmark$ \\
\hline \multirow[t]{3}{*}{ Lantai 6} & Pekerjaan dinding & $\checkmark$ & $\checkmark$ & $\checkmark$ & $\checkmark$ & $\checkmark$ \\
\hline & Pekerjaan Plafon & $\checkmark$ & $\checkmark$ & $\checkmark$ & $\checkmark$ & $\mathrm{x}$ \\
\hline & Pekerjaan Keramik & $\checkmark$ & $\checkmark$ & $\checkmark$ & $\checkmark$ & $\mathrm{x}$ \\
\hline \multirow[t]{3}{*}{ Lantai 7} & Pekerjaan dinding & $\checkmark$ & $\checkmark$ & $\checkmark$ & $\checkmark$ & $\checkmark$ \\
\hline & Pekerjaan Plafon & $\checkmark$ & $\checkmark$ & $\checkmark$ & $\checkmark$ & $\checkmark$ \\
\hline & Pekerjaan Keramik & $\checkmark$ & $\checkmark$ & $\checkmark$ & $\checkmark$ & $\mathrm{x}$ \\
\hline \multirow[t]{3}{*}{ Lantai 8} & Pekerjaan dinding & $\checkmark$ & $\checkmark$ & $\checkmark$ & $\checkmark$ & $\checkmark$ \\
\hline & Pekerjaan Plafon & $\checkmark$ & $\checkmark$ & $\checkmark$ & $\checkmark$ & $\checkmark$ \\
\hline & Pekerjaan Keramik & $\checkmark$ & $\mathrm{x}$ & $\checkmark$ & $\checkmark$ & $\mathrm{x}$ \\
\hline \multirow[t]{3}{*}{ Lantai 9} & Pekerjaan dinding & $\checkmark$ & $\mathrm{x}$ & $\checkmark$ & $\checkmark$ & $\mathrm{x}$ \\
\hline & Pekerjaan Plafon & $\checkmark$ & $\mathrm{x}$ & $\checkmark$ & $\checkmark$ & $\mathrm{x}$ \\
\hline & Pekerjaan Keramik & $\checkmark$ & $\mathrm{x}$ & $\checkmark$ & $\checkmark$ & $\mathrm{x}$ \\
\hline \multirow[t]{3}{*}{ Lantai 10} & Pekerjaan dinding & $\checkmark$ & $\checkmark$ & $\checkmark$ & $\checkmark$ & $\checkmark$ \\
\hline & Pekerjaan Plafon & $\checkmark$ & $\mathrm{x}$ & $\checkmark$ & $\checkmark$ & $\mathrm{x}$ \\
\hline & Pekerjaan Keramik & $\checkmark$ & $\mathrm{x}$ & $\checkmark$ & $\checkmark$ & $\mathrm{x}$ \\
\hline
\end{tabular}

Dari tabel 5 , tanda ceklist $(\checkmark)$ menunjukkan constrain/predecessor (syarat agar pekerjaan dapat dikerjakan) telah terpenuhi. Tanda silang (x) menunjukkan constrain/predecessor tidak terpenuhi.

\subsubsection{Shielding production analysis}

Tujuan dari shielding production analysis adalah menyaring assignment yang berkualitas dan mengidentifikasi penyebab terjadinya hambatan (constrain) yang telah dijelaskan sebelumnya. Pada penelitian ini shielding production analysis juga dilakukan setiap pagi hari setelah melakukan pengisian constrain analysis. Adapun shielding production dalam penelitian ini sebagai berikut:

1. Assignment yaitu definisi pekerjaan yang direncanakan pada tanggal yang ditinjau.

2. Soundness yaitu pernyataan kemungkinan assignment tersebut untuk dikerjakan.

3. Crew size yaitu kesiapan pekerja.

4. Learning yaitu pembelajaran atau identifikasi masalah yang terjadi pada tanggal yang ditinjau.

\subsection{Perhitungan PPC}

PPC dihitung dari jumlah assignments yang selesai dikerjakan dibagi dengan jumlah rencana assignments dan ditulis dalam bentuk persentase. Jumlah assignments yang telah 
selesai diperoleh dari kecepatan kerja aktual dibagi dengan kecepatan kerja rencana yang masuk dalam DWP kemudian hasilnya dijumlahkan. Total jumlah rencana pekerjaan (total work plans) adalah jumlah pekerjaan yang masuk dalam DWP. Contoh hasil perhitungan PPC dapat dilihat pada Tabel 6.

Tabel 6. Hasil perhitungan PPC tanggal 19 Maret

\begin{tabular}{|c|c|c|c|c|c|c|c|}
\hline Area & Assignment & $\begin{array}{l}\text { Progress } \\
\text { kerja } \\
\text { rencana } \\
\text { (i) }\end{array}$ & $\begin{array}{l}\text { Progress } \\
\text { kerja } \\
\text { aktual } \\
\text { (ii) }\end{array}$ & $\begin{array}{l}\text { Completed } \\
\text { work } \\
(\mathrm{iii}=\mathrm{ii} / \mathrm{i})\end{array}$ & $\begin{array}{l}\text { Total } \\
\text { completed } \\
\text { work } \\
\left(\sum \text { iii) }\right.\end{array}$ & $\begin{array}{l}\text { Total } \\
\text { work } \\
\text { plans } \\
\text { (iv) }\end{array}$ & $\begin{array}{l}\text { PPC } \\
\left(\sum\right. \\
\text { iii/iv x } \\
100 \%)\end{array}$ \\
\hline \multirow[t]{3}{*}{ Lantai 5} & Pekerjaan dinding & $2 \%$ & $1 \%$ & 0,5 & \multirow{18}{*}{4,6} & \multirow{18}{*}{18} & \multirow{18}{*}{$25,6 \%$} \\
\hline & Pekerjaan Plafon & $3 \%$ & $2 \%$ & 0,7 & & & \\
\hline & $\begin{array}{l}\text { Pekerjaan } \\
\text { Keramik }\end{array}$ & $4 \%$ & $3 \%$ & 0,8 & & & \\
\hline \multirow{3}{*}{$\begin{array}{l}\text { Lantai } \\
6\end{array}$} & Pekerjaan dinding & $2 \%$ & $1 \%$ & 0,5 & & & \\
\hline & Pekerjaan Plafon & $4 \%$ & $0 \%$ & 0,0 & & & \\
\hline & $\begin{array}{l}\text { Pekerjaan } \\
\text { Keramik }\end{array}$ & $3 \%$ & $0 \%$ & 0,0 & & & \\
\hline \multirow[t]{3}{*}{ Lantai 7} & Pekerjaan dinding & $3 \%$ & $2 \%$ & 0,7 & & & \\
\hline & Pekerjaan Plafon & $2 \%$ & $1 \%$ & 0,5 & & & \\
\hline & $\begin{array}{l}\text { Pekerjaan } \\
\text { Keramik }\end{array}$ & $4 \%$ & $0 \%$ & 0,0 & & & \\
\hline \multirow{3}{*}{$\begin{array}{l}\text { Lantai } \\
8\end{array}$} & Pekerjaan dinding & $2 \%$ & $1 \%$ & 0,6 & & & \\
\hline & Pekerjaan Plafon & $2 \%$ & $0 \%$ & 0,0 & & & \\
\hline & $\begin{array}{l}\text { Pekerjaan } \\
\text { Keramik }\end{array}$ & $1 \%$ & $0 \%$ & 0,0 & & & \\
\hline \multirow{3}{*}{$\begin{array}{l}\text { Lantai } \\
9\end{array}$} & Pekerjaan dinding & $4 \%$ & $0 \%$ & 0,0 & & & \\
\hline & Pekerjaan Plafon & $3 \%$ & $0 \%$ & 0,0 & & & \\
\hline & $\begin{array}{l}\text { Pekerjaan } \\
\text { Keramik }\end{array}$ & $3 \%$ & $0 \%$ & 0,0 & & & \\
\hline \multirow{3}{*}{$\begin{array}{l}\text { Lantai } \\
10\end{array}$} & Pekerjaan dinding & $2 \%$ & $1 \%$ & 0,5 & & & \\
\hline & Pekerjaan Plafon & $3 \%$ & $0 \%$ & 0,0 & & & \\
\hline & $\begin{array}{l}\text { Pekerjaan } \\
\text { Keramik }\end{array}$ & $3 \%$ & $0 \%$ & 0,0 & & & \\
\hline
\end{tabular}

Dari rekapitulasi yang dilakukan, selanjutnya dihitung rata-rata PPC harian dimana nilai rata-rata PPC tersebut menunjukkan nilai produktivitas rata-rata proyek dan kinerja kontraktor selama penelitian. Rekapitulasi hasil perhitungan PPC dapat dilihat di Tabel 7.

Tabel 7. Rekapitulasi hasil perhitungan PPC

\begin{tabular}{llll}
\hline Minggu ke- & Tanggal & $\begin{array}{l}\text { PPC } \\
(\text { harian })\end{array}$ & $\begin{array}{l}\text { Rata-Rata PPC } \\
\text { Mingguan }\end{array}$ \\
\hline \multirow{2}{*}{28} & 19 Maret & $25 \%$ & \\
\cline { 2 - 3 } & 20 Maret & $37 \%$ & \multirow{2}{*}{$51 \%$} \\
\cline { 2 - 3 } & 21 Maret & $41 \%$ & \\
\cline { 2 - 3 } & 22 Maret & $68 \%$ & $62 \%$ \\
\cline { 2 - 3 } 29 & 23 Maret & $69 \%$ \\
\cline { 2 - 3 } & 24 Maret & $69 \%$ & $52 \%$ \\
\hline
\end{tabular}


Implementasi Last Planner System Pada Proyek di Palembang (Studi Kasus : Proyek Rusunami Jakabaring)

\begin{tabular}{|c|c|c|c|}
\hline Minggu ke- & Tanggal & $\begin{array}{l}\text { PPC } \\
\text { (harian) }\end{array}$ & $\begin{array}{l}\text { Rata-Rata PPC } \\
\text { Mingguan }\end{array}$ \\
\hline & 28 Maret & $66 \%$ & \\
\hline & 29 Maret & $50 \%$ & \\
\hline & 30 Maret & $49 \%$ & \\
\hline & 31 Maret & $69 \%$ & \\
\hline & 1 April & $71 \%$ & \\
\hline \multirow{7}{*}{30} & 2 April & $62 \%$ & \multirow{7}{*}{$82 \%$} \\
\hline & 3 April & $106 \%$ & \\
\hline & 4. April & $85 \%$ & \\
\hline & 5 April & $83 \%$ & \\
\hline & 6 April & $105 \%$ & \\
\hline & 7 April & $74 \%$ & \\
\hline & 8 April & $62 \%$ & \\
\hline \multirow{7}{*}{31} & 9 April & $73 \%$ & \multirow{7}{*}{$80 \%$} \\
\hline & 10 April & $88 \%$ & \\
\hline & 11 April & $76 \%$ & \\
\hline & 12 April & $84 \%$ & \\
\hline & 13 April & $81 \%$ & \\
\hline & 14 April & $78 \%$ & \\
\hline & 15 April & $81 \%$ & \\
\hline \multirow{7}{*}{32} & 16 April & $73 \%$ & \multirow{7}{*}{$79 \%$} \\
\hline & 17 April & $74 \%$ & \\
\hline & 18 April & $77 \%$ & \\
\hline & 19 April & $88 \%$ & \\
\hline & 20 April & $78 \%$ & \\
\hline & 21 April & $84 \%$ & \\
\hline & 22 April & $81 \%$ & \\
\hline \multirow{7}{*}{33} & 23 April & $84 \%$ & \multirow{7}{*}{$91 \%$} \\
\hline & 24 April & $89 \%$ & \\
\hline & 25 April & $93 \%$ & \\
\hline & 26 April & $91 \%$ & \\
\hline & 27 April & $89 \%$ & \\
\hline & 28 April & $94 \%$ & \\
\hline & 29 April & $95 \%$ & \\
\hline \multicolumn{2}{|c|}{ Rata-rata PPC } & & $73 \%$ \\
\hline
\end{tabular}

Dari hasil PPC tersebut, dapat dilihat bahwa rata-rata PPC adalah $73 \%$ yang artinya LPS dapat meningkatkan reabilitas perencanaan di atas $70 \%$. Hal ini menunjukkan bahwa meskipun hanya pada pekerjaan finishing, LPS sudah mendekati daripada progress aktual, sehingga apabila perencanaan suatu proyek telah menggunakan metode LPS sejak awal, maka reabilitas perencanaan akan melebihi persentase yang telah dicapai pada penelitian ini. Dengan semakin meningkatnya reabilitas perencanaan maka semakin kecil pula tingkat resiko terjadinya keterlambatan proyek, sehingga kontraktor akan lebih merasa diuntungkan.

\subsubsection{Perbandingan PPC Menggunakan LPS dan Progress di Lokasi Proyek}

Untuk membuktikan bahwa perhitungan PPC yang dilakukan sesuai dengan kondisi di lokasi proyek, maka dilakukan perbandingan data dari hasil perhitungan PPC menggunakan LPS dengan progress data mingguan pada minggu ke 30 hingga minggu ke 33 di lokasi proyek yang didapat dari pihak kontraktor. Adapun perbandingan data tersebut dapat dilihat pada Tabel 8. 
Tabel 8. Perbandingan data PPC LPS dan data progress mingguan kontraktor

\begin{tabular}{lll}
\hline Minggu ke- & Hasil PPC LPS & Progress di Lokasi Proyek \\
\hline 30 & $82 \%$ & $83 \%$ \\
\hline 31 & $80 \%$ & $82 \%$ \\
\hline 32 & $79 \%$ & $82 \%$ \\
\hline 33 & $91 \%$ & $97 \%$ \\
\hline
\end{tabular}

Dari hasil perbandingan data tersebut dapat dilihat bahwa hasil PPC mingguan tidak jauh berbeda dengan hasil data progress mingguan yang didapat dari pihak kontraktor. Adapun selisih yang cukup signifikan didapat pada minggu ke 33 dikarenakan beberapa progress item pekerjaan seperti pekerjaan keramik dan pekerjaan plafond seringkali dianggap telah selesai $100 \%$ oleh pihak kontraktor meskipun pekerjaan tersebut masih dalam proses pengerjaan. Hal ini berbeda dengan penilaian progress pekerjaan menggunakan LPS yaitu jika pada pekerjaan tersebut belum diselesaikan dengan sesuai maka pekerjaan tersebut tidak dapat disebut selesai $100 \%$. Akibat perbedaan presepsi ini, sehingga perbedaan yang sebenarnya tidak terlihat signifikan, tetapi dikarenakan progress aktual dihitung dalam mingguan, maka akumulasi persentase dari semua item pekerjaan terlihat cukup berbeda (sebesar 6\%) jika dibanding dengan PPC menggunakan LPS.

\section{KESIMPULAN DAN SARAN}

Adapun kesimpulan dari penelitian ini, yaitu:

1. Dari hasil perbandingan data tersebut dapat dilihat bahwa hasil PPC mingguan tidak jauh berbeda dengan hasil data progress mingguan yang didapat dari pihak kontraktor. Adapun selisih yang cukup signifikan didapat pada minggu ke 33 dikarenakan beberapa progress item pekerjaan seperti pekerjaan keramik dan pekerjaan plafond seringkali dianggap telah selesai $100 \%$ oleh pihak kontraktor meskipun pekerjaan tersebut masih dalam proses pengerjaan. Hal ini berbeda dengan penilaian progress pekerjaan menggunakan LPS yaitu jika pada pekerjaan tersebut belum diselesaikan dengan sesuai maka pekerjaan tersebut tidak dapat disebut selesai $100 \%$. Akibat perbedaan presepsi ini, sehingga perbedaan yang sebenarnya tidak terlihat signifikan, tetapi dikarenakan progress aktual dihitung dalam mingguan, maka akumulasi persentase dari semua item pekerjaan terlihat cukup berbeda (sebesar 6\%) jika dibanding dengan PPC menggunakan LPS.

2. Hasil implementasi menggunakan LPS pada proyek pembangunan rusunami Jakabaring menunjukkan bahwa pekerjaan finishing/arsitektur proyek mempunyai nilai PPC sebesar $73 \%$ yang artinya yang artinya LPS dapat meningkatkan reabilitas perencanaan di atas $70 \%$.

3. Faktor-faktor dominan yang menyebabkan keterlambatan pekerjaan proyek dalam studi kasus ini yaitu:

- Faktor pekerja, yaitu pekerja tidak ada di lokasi proyek atau pekerja bekerja di lantai yang berbeda sehingga pekerjaan di lantai tersebut terhambat.

- Faktor material, yaitu belum tersedianya material pada lantai tertentu yang menyebabkan pekerjaan terhambat.

- Faktor Prodecessor, yaitu pihak ME belum melakukan pemasangan electrical sehingga menghambat pekerjaan yang telah direncanakan.

Adapun saran untuk pelaksanaan proyek konstruksi ini maupun penelitian kedepan, yaitu: 
1. Penelitian menggunakan LPS ini sebaiknya dilakukan pada saat perencanaan proyek (sebelum proyek terlaksana) hingga proyek selesai sehingga kontrol aliran LPS diharapkan dapat menghasilkan nilai PPC yang lebih mendekati daripada progress aktual di lokasi proyek.

Penelitian selanjutnya diharapkan dapat dilakukan dengan lebih baik untuk menerapkan metode pull sehingga setiap langkah dalam kontrol aliran kerja LPS dapat dilakukan secara penuh.

\section{DAFTAR PUSTAKA}

Abduh, M., (2005). Konstruksi Ramping: Memaksimalkan Value dan Meminimalkan Waste. Bandung: Fakultas Teknik Sipil dan Lingkungan ITB.

Adamu, I., \& Howell, G. (2012). Applying Last Planner in The Nigerian Construction Industry. Proceedings of the 20 Annual Conference of the International Group for Lean Construction, Nigeria.

Arifin, A. (2017). Eksplorasi Penggunaan Last Planner System untuk Monitoring dan Evaluasi Progress Pekerjaan Proyek Konstruksi (Skripsi). Departemen Teknik Sipil dan Lingkungan, Universitas Gadjah Mada, Yogyakarta.

Ballard, G., (2000). The Last Planner System Of Production Control (Theses). School of Civil Engineering Faculty of Engineering The University of Birmingham. UK.

Ballard, G., \& Howell, G. (2004). Competing construction management paradigms. Lean Construction Journal, 1(1), 38-45.

Forbes, L. H., Ahmed, S. M., \& Barcala, M. (2002, November). Adapting lean construction theory for practical application in developing countries. In Proceedings of the first CIB W107 International Conference: Creating a Sustainable Construction Industry in Developing Countries, Stellenbosch, South Africa (Vol. 11, p. 13).

Herry, (2015). An Introduction Do Pull Planning: Los Angeles, U.S.A.

Lean Construction Institute. (2015). Lean Project Delivery Glossary. Lean Construction Institute.

Mossman, A. (2013). Last Planner ${ }^{\circledR}: 5+1$ crucial \& collaborative conversations for predictable design \& construction delivery. The Change Business Ltd., UK, 26.

Mudzakir, A. C., Setiawan, A., Wibowo, M. A., \& Khasani, R. R. (2017). Evaluasi Waste Dan Implementasi Lean Construction (Studi Kasus: Proyek Pembangunan Gedung Serbaguna Taruna Politeknik Ilmu Pelayaran Semarang). Jurnal Karya Teknik Sipil, 6(2), 145-158.

Munje, A. S., \& Patil, D. S. (2014). Comparative study of last planner system over traditional construction processes. Current Tren. Tech. Sci, 3, 308-311.

Patel, A. (2011). The Last Planner System For Reliable Project Delivery (Thesis). Arlington, University Of Texas, U.S.A.

Proboyo, B. (2004). Keterlambatan Waktu Pelaksanaan Proyek Klasifikasi dan Peringkat dari Penyebab-Penyebabnya. Civil Engineering Dimension, 1(1), 46-58.

Steven, S., Robby, R., \& Andi, A. (2013). Perhitungan Percent Plan Completed Dan Identifikasi Faktor Tidak Tercapainya Rencana Pekerjaan Pada Suatu Proyek Konstruksi. Jurnal Dimensi Pratama Teknik Sipil, 2(2).

Wijaya, M. R. A., Hatmoko, J. U. D., \& Suripin, (2015). Assessment of Lean Construction Principles: A Case Study at Semarang Medical Centre Hospital Project. Jurnal Ilmu dan Terapan Bidang Teknik Sipil, Undip, 21(2). Semarang. 